\title{
RELATIONSHIP BETWEEN LEVEL OF EDUCATION AND EMPLOYEES OF PARENTS WITH CHILDREN AT HOME ON THE CHARACTER OF PEOPLE PARTICIPANTS
}

\author{
Halimatussakdiah \\ Surel : halimatussakdiahnst11@gmail.com
}

\begin{abstract}
This study aims to determine the relationship level of education and intimacy of parents with children at home to the character of students in class IV SDN 106811 Bandar Setia. This research belongs to correlational research using quantitative descriptive method. The sample in this research is the students of class IVA and IVB SD Negeri 106811 Bandar Setia which amounted to 64 people. Based on the results of research and hypothesis testing showed that: There is no positive and significant relationship between the level of education of parents to the character of learners; There is a positive and significant relationship between the parent's familiarity with the child at home to the character of the students; And There is a positive and significant relationship between the level of parent education and the familiarity of parents with children at home to the character of learners.
\end{abstract}

Keywords: Character, Education Level, Parent's Familiarity with Children

\section{INTRODUCTION}

The rapid development of science and technology nowadays leads people to continue to develop insight and ability in various fields of education. Education is very important for mankind and cannot be separated from human life, then education should be implemented as well as possible so that will get the results that will be expected. The nation who want to go forward, build and try to improve the state of society and the world cannot be separated from efforts to improve the quality of education nation own. This increase is the same as improving Human Resources (HR). Therefore education becomes a very important thing to be developed, so that the development of human resources in the field of education is the main capital in the nation's development.

In school children are given education not only to be good at mastering knowledge but it is not less important is to build the character of learners. As the results of research at Harvard University United States according to Ali Ibrahim (Hasbullah: 2005) explained that:

"The success of one's life is not determined solely by the knowledge and technical skills (hard skills) acquired through education, but rather by the ability to manage oneself which includes the character and others (soft skills). This research

The Lectures Of Universitas Negeri Medan 
reveals that one's success is determined only about $20 \%$ by hard skill and the remaining $80 \%$ soft skill. Even the most successful people in the world can succeed because more supported the ability of soft skills than hard skills.

The above opinion can be concluded that the success of a learner is not only seen from the knowledge alone but the character of the learner is very important to be developed. With the development of character will form a nation of children with good character. Character education is not expected only within the school, but the first and foremost is in the family.

But the reality of students is still not good, it can be seen from Kompas News 12 April 2011, "Mass contest case during national exam (UN) 2011, elementary school level (SD), which happened at SDN Gadel, Tandes, Surabaya". Our society is currently experiencing a moral crisis or character. The problem of characters that occur today is much more complex than in previous times. The issue of character becomes a very serious thought material and very apprehensive at this time. The moral crisis not only occurs in adults, but also among children.

Children have different characteristics with other students. One characteristic of a child between 10-12 years old or high school grade is to enjoy active play, pride and high-skill skills, seek adult attention, be excited, his emotional state is unstable, begin to understand the meaning of time and want to achieve something in time.

Students' misbehavior refers to morals that can disrupt the process of learning activities such as stealing, fighting with classmates, harassing friends who are learning, taking belongings of friends, noisy in the classroom, not collecting tasks, banging tables, eating at school And whispered in a lesson. In this case the parents have the task to awaken and direct the child to have a good character.

The phenomenon of the decline of national character in the country can be caused by the level of education. Education level is divided into several levels, ie SD / MI, SMP / MTs, SMA / SMK / MA and Higher Education. The higher level of education and insight that parents have can be influential in educating children who can ultimately shape the child's character. The person who has the education will look at his attitude, speech and association. In addition, both parents should establish intimacy with their children at home. Parents' familiarity with children is showing affection, caring, giving a good example of their child.

The family also has a very important role in the development of the character of the child, in addition the child has a lot of time and bond 
between parents and children. With the existence of a lot of time between parents with children who will cause a sense of comfort, tentram so that children easily explore the behavior in accordance with the character implanted parents. Child cultivation of early character is very influential on the development of children in the future because if children from early on cannot be educated from the parents then have a weak character. The child as an adult will be disconcerted in determining the direction of his life even more so the child can easily enter into negative things. Therefore, the family must carefully and carefully in the planting of characters in children - especially at the age of primary school.

In connection with the main task of the family for the education of children is as the foundation of moral education and religious life. The nature and character of the child is largely derived from both his parents and other family members. Where is the parent's responsibility to the child? For a child, the family is a living alliance of the family environment in which it becomes a self or a self. The family is also a place for children in the context of their learning process to develop and shape themselves in their social function.

In accordance with Law No. 2 of 1989 on National Education System Article 10 paragraph 4
(Hasbullah, 2005: 287) it is stated that "Family education is part of the outof-school education channel that is held in the family and provides religious beliefs, cultural values, moral values, and Skills ". This shows that the family environment provides confidence in worship, cultural values, courtesy of the elderly and the skills of the child.

The current state of education and intimacy of parents with children in the family is very sad. Where families now regard education as unimportant to their children and many divorces, beating up their children, abusing and even killing their own children in the family. The circumstances mentioned above show that many parents are not paying attention.

In addition, the behavior of children in school are many who deviate. Seen in the case of the child contained in Sindonews On March 12, 2015 on "Elementary Children who beat their friends to death". This shows the act of beating up a friend is a child action that requires monitoring from parents and community to avoid things like this.

Therefore, the formation of the character of the nation must be started early on by both the parents at home, the community in the environment and institutions of education institutions. Of the several events that have been described above, indicates that education and 
intimacy of parents with children in the house is needed Not happen things - things that are not in accordance with what has been described above. The many characters of deviant children in this day and age require more selective parents in applying education and intimacy of parents with children so that children have a better character again.

This situation encourages the authors to conduct research with the title "Relationship Between Level Of Education And Employees Of Parents With Children At Home On The Character Of People Participants".

\section{RESEARCH METHODS}

In this study using the type of quantitative research using correlational techniques. This research is located in SD Negeri 106811 Bandar Setia, Percut Sei Tuan District, Deli Serdang district. The study was conducted in January Semester Even 2017. Population in this study were all students of grade IV SDN 106811 Bandar Setia.

\begin{tabular}{ccc}
\hline No & Kelas & Jumlah Siswa \\
\hline 1. & IVA & 31 \\
2. & IVB & 33 \\
& Jumlah & 64 Siswa \\
\hline
\end{tabular}

According to Arikunto (2006) that, "If the subject of a person is less than 100 people, the sample is better taken all, so the research is a population study. However, if the subject is large, it can be taken between $10-15 \%$ or more of the subject. Based on the above opinion, the number of samples taken with a random sample is 64 people (total sampling).

Data collection for parents education variables is done by documentation study and data collection for parents' parenting variables with children at home and the character of the learner is done by dispatching the questionnaire. The results of this study were analyzed using statistical techniques that are description analysis, data trend test, correlation test, regression test and hypothesis testing.

Criteria used in this research is reject the hypothesis stating that there is no positive and meaningful relationship between independent variables with dependent variable if price $t_{\text {count }}>t_{\text {table }}$.

Test the questionnaire instrument is done by testing the validity and reliability before it is distributed to the actual respondent.

For validity testing done by using product moment statistics proposed by Arikunto, (2006: 211) the formula used:

$$
r_{x y}=\frac{n \sum x y-\left(\sum x\right)\left(\sum y\right)}{\sqrt{\left[n \sum x^{2}\left(\sum x^{2}\right)\right]\left[n \sum y^{2}\left(\sum y^{2}\right)^{2}\right]}}
$$


For reliability questionnaire used alpha coefficient formula by Arikunto (2013: 239) as follows:

$$
r_{11}=\left[\frac{k}{k-1}\right]\left[1-\frac{\sum a_{b}^{2}}{a_{1}^{2}}\right]
$$

\section{DISCUSSION}

In the calculation of correlation between research variables obtained correlation coefficient between the level of parental education to the character of learners untested truth, because based on the calculation of correlation coefficient analysis between the level of education with the character of learners is $r_{x 1 y}=-0.016$. The value of $t_{\text {count }}$ is -0.129 with regression equation $\quad Y^{\prime}=95.007-0.240 X_{1}$. While the value of $t_{\text {count }}$ is smaller than the value of $t_{\text {table, }}$ is $-0.129<$ 2.000. Then $\mathrm{H}_{0}$ is accepted.

So it can be concluded that there is no positive and significant relationship between the level of education to the character of learners in SD Negeri 106811 Bandar Setia.

The results of the documentation of the level of education of parents in the VA and VB classes are in moderate category, the level of education of the parents of students is at the high school level. Parents who have higher education tend to be preoccupied with activities outside the home. So parents are not maximized in giving attention to their children. Because basically the family is the first place in the process of individual formation other than environmental factors. This is in line with the opinion of Helen G Douglas, "the character is not inherited but something that is built continuously day by day through thoughts and deeds, mind by thought, action for action".

From the opinion above can be concluded that the level of education is not directly as a form of the character of the learner (child) but the character tesebut formed from continuous attention so as to form thoughts and deeds that become the character of the child.

In the calculation of correlation between research variables obtained correlation coefficient between the familiarity of parents with children at home to the character of learners is correctness. This proof obtained be based on calculation of correlation coefficient analysis between the parent familiarity with the character of learners is $r_{x 2 y}=$ 0.442 The value of $t_{\text {count }}$ is 4,323 with regression equation $Y^{\prime}=46.160+$ $0.554 X_{2}$. While the value of $t_{\text {count }}$ smaller than the value of $t_{\text {table, }}$ which is $4.323>2.000$. Then $\mathrm{H}_{0}$ is rejected.

So it can be concluded that there is a positive and significant relationship between the familiarity of parents with children at home to the character of learners in SD Negeri 106811 Bandar Setia. 
This result is because characters can be formed through good interaction or in other words the occurrence of good communication between children and parents. With this, the child will have good behavior because of interwoven open / communication between children with parents, especially to his mother. Because the first child knows the mother tongue.

This is in line with Chen's opinion (in Lestari: 2012), "the quality of parent-child relationships reflects the level of warmth, security, trust, positive affection and responsiveness in their relationships. Warmth becomes a fundamental component of parent-child relationships that can make Children feel loved and develop selfconfidence". Warmth provides the context for positive affections that will increase the mood for caring and responses to each other.

From the above opinion can be concluded that the quality of parent relationship to the child will give a positive thing that is apektif (deed/behavior) of the child.

In the calculation of correlation between research variables obtained correlation coefficient between the level of education and the familiarity of parents to the character of the learners are tested for truth. This proof is obtained based on the calculation of coefficient analysis of education level and parental familiarity to the learner character of 0.442. The double correlation coefficient indicates that the two relationships between the two independent variables together with the dependent variable are positive and the interpretation is moderate.

So it can be concluded that there is a positive and significant relationship between the variables level of education and parents' familiarity with the character of learners in SD Negeri 106811 Bandar Setia.

From the result of $F$ test that $F_{\text {count }}$ is 7,399 . While the value $F_{\text {table }}$ with degrees of freedom $d f_{1}=$ the number of variables -1 or $3-1=2$, degrees of freedom $\left(d f_{2}\right)=n-k-$ 1or $64-2-1=61$ and at the level of significance $\alpha=0.05$. The $F_{\text {count }}$ value is greater than the $F_{\text {tabel }}$ value is 7.399> 4.001. Decision making criteria if $\mathrm{F}_{\text {count }}>\mathrm{F}_{\text {table }}$ then $\mathrm{H}_{0}$ is rejected.

So it can be concluded that there is a significant influence between the level of parental education and the familiarity of parents with children at home to the character of learners.

The result of determination coefficient analysis $\left(\mathrm{R}^{2}\right)$ between educational level and parent familiarity to the character of learners is 0.1954 or $19.54 \%$. This shows that the percentage contribution of influence together that is level of education and intimacy of parent to 
character of learners equal to $19.54 \%$. While the rest of $80.46 \%$ influenced or explained by other variables not examined in this research model.

The correlation between the variables of the level of education and the familiarity of the parents towards the character of the learner can be illustrated as shown below:

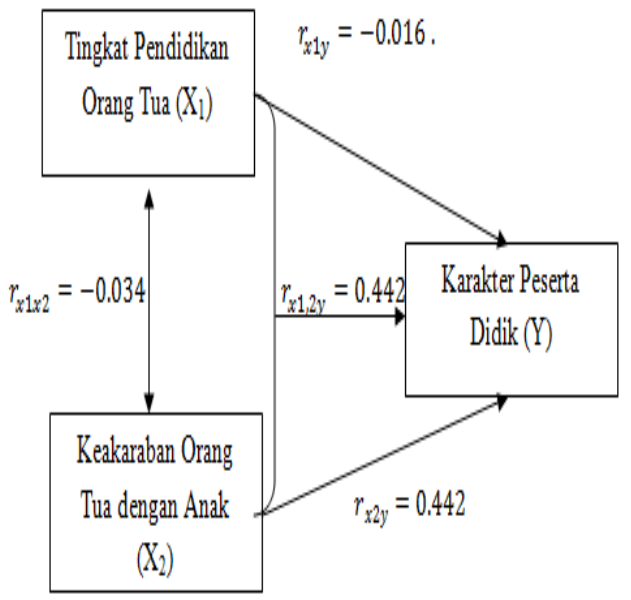

\section{CONCLUSION}

From the research results can be obtained the following conclusions:

1. There is no positive and significant correlation between the education level of parents to the character of the students in SD Negeri 106811 Bandar Setia. In the calculation of correlation between research variables obtained correlation coefficient between parental education level to the character of learners is equal to $r_{x 1 y}=-0.16$ and value $t_{\text {hitung }}<t_{\text {tabel }}$ is $-0.129<2.000$.
This means that the high level of education parents have no relationship with the character of learners in SD Negeri 106811 Bandar Setia.

2. There is a positive and significant relationship between parents' intimacy with children at home to the character of learners in SD Negeri 106811 Bandar Setia. In the calculation of correlation between research variables obtained correlation coefficient between parents' intimacy with children at home to the character of learners is equal to $r_{x 1 y}=$ 0.000 and $t_{\text {hitung }}>t_{\text {tabel }}$, is 4.323> 2.000. This means that the closer the intimacy of parents with children at home will have a positive relationship with the character of students in SD Negeri 106811 Bandar Setia.

3. There is a positive and significant relationship between the level of parent education and the familiarity of parents with children at home to the character of learners in SD Negeri 106811 Bandar Setia. In the calculation of correlation between research variables obtained correlation coefficient between the level of parent education and the familiarity of parents with children at home to the character of learners is 0.442 . This means that the higher level of education and close intimacy of parents with 
children at home will have a positive relationship with the character of students in SD Negeri 106811 Bandar Setia.

BIBLIOGRAPHY

Adisusilo, $\quad$ Sutarjo. 2014 Pembelajaran Nilai Karakter. Jakarta: Raja Grafindo Persada.

Anisa. 2014. Faktor yang Mempengaruhi Karakter dalam

https://www.google.co.id/ search? $q=$ faktor + yang + me mpengaruhi + karakter\&oq $=f$ aktor+yang +mempengaruhi + karakter. html. Diakses 25 Oktober 2016, 13.25 WIB.

Arikunto. 2006. Metodologi Penelitian. Jakarta: Alfabeta.

Anonim. 2013. Prosedur Penelitian Jakarta: Rineka Cipta.

Depdiknas. Undang-Undang Sistem Pendidikan Nasional No 20 Tahun 2003.

Depdiknas. Undang - Undang No 35 Tahun 2014

Hasbullah. 2005. Dasar - Dasar Pendidikan. Jakarta: Raja Grafindo.
Lestari, Sri. 2012. Psikologi Keluarga. Yogyakarta: Kencana.

Muhibbinsyah. 2011. Psikologi Pendidikan. Bandung: Rosdakarya.

Peraturan Presiden Republik Indonesia 60 Tahun 2013 tentang Pengembangan Anak Usia Dini Holistik-Integratif. 2013. Jakarta. Kementrian Pendidikan dan Kebudayaan.

Purba, Edward \& Yusnadi. 2015. Filsafat Pendidikan. Medan: Unimed Press.

Rio. 2011. Faktor yang Mempengaruhi Keakraban Orang Tuadengan Anak dalam http://rioronaldo.blogspot.com/2011/ 10/faktor-faktor-yangmempengaruhi-orang tua dengan anak. html. Diakses 05 Desember 2016, 14.30 WIB.

Sagala, Syaiful. 2005. Konsep dan Makna Pembelajaran. Bandung: Alfabeta.

Sahlan dan Prastyo. 2012. Pendidikan Karakter. Bandung: Alfabeta.

Said, Moh. 2010. Pendidikan Karakter di Sekolah. Surabaya: Jaring Pena. 
Halimatussakdiah: Relationship Between Level ..

Samani, Muchlas \& Hariyanto. 2012. Yudi, Latif. 2007. Pendidikan Konsep dan Model Pendidikan Karakter. Karakter. Bandung: Rineka Bandung: Remaja

Rosdakarya. 